\title{
Urine patches indicate yield potential of cocksfoot
}

\author{
P.L. PERI ${ }^{1,2}$, D.J. MOOT ${ }^{1}$ and R.J. LUCAS ${ }^{1}$ \\ ${ }^{1}$ Soil, Plant and Ecological Sciences Division, P.O. Box 84, Lincoln University, Canterbury \\ ${ }^{2}$ Universidad Nacional de la Patagonia Austral-INTA. CC 332 (CP 9400), Río Gallegos, Santa Cruz, Argentina \\ mootd@lincoln.ac.nz
}

\begin{abstract}
Dry matter $(\mathrm{DM})$ production and crude protein $(\mathrm{CP} \%)$ of sheep urine patches in a grazed cocksfoot pasture (28 day rotation with $21 \pm 1$ days regrowth) were measured at Lincoln University from September 1999 to May 2001. Also, the DM response from artificial urine patches was measured over time. The rate of nitrogen (N) applied per hectare in an individual urine patch was $173 \mathrm{~kg} \mathrm{~N} / \mathrm{ha}$ in autumn compared with $448 \mathrm{~kg} \mathrm{~N} / \mathrm{ha}$ in spring. This stimulated a maximum difference in DM production between urine patches and controls over a 21 day period of $1970 \mathrm{~kg} \mathrm{DM} / \mathrm{ha}$ in spring (October). Smaller differences were measured in summer $(380 \mathrm{~kg}$ $\mathrm{DM} / \mathrm{ha})$ and winter $(370 \mathrm{~kg} \mathrm{DM} / \mathrm{ha})$. The maximum difference in $\mathrm{CP} \%$ was also in spring being $27.0 \%$ for urine patches and $18.7 \%$ for controls. DM production differences were attributed to differences in net leaf photosynthetic rate, which ranged from 23.5 in spring to $4.5 \mu \mathrm{mol} \mathrm{CO} \mathrm{C}^{-2} \mathrm{~s}^{-1}$ in summer. Leaf photosynthetic rate was limited solely by $\mathrm{N}$ supply in spring, by soil moisture (mean soil volumetric water content in the top $500 \mathrm{~mm}<20 \%)$ and leaf $\mathrm{N}$ content $(<3 \% \mathrm{~N})$ in summer and mainly by low temperatures $\left(<9^{\circ} \mathrm{C}\right)$ but also $\mathrm{N}$ supply in winter. The low temperature in winter also meant the duration of urine patch response was 133 days compared with 105 days in spring and 77 days in summer. In a second experiment, the DM response of cocksfoot to synthetic urine ( $300 \mathrm{~kg} \mathrm{~N} / \mathrm{ha}$ ) and irrigation was examined in ungrazed areas (four 60-day regrowth periods and one 110-day winter regrowth). From these treatments, the maximum annual DM production for cocksfoot with irrigation and $\mathrm{N}$ was $28.6 \mathrm{t} \mathrm{DM} / \mathrm{ha} / \mathrm{yr}$ compared with $9.2 \mathrm{t} \mathrm{DM} / \mathrm{ha} / \mathrm{yr}$ for the control. The addition of irrigation alone yielded $13.0 \mathrm{t} \mathrm{DM} / \mathrm{ha} / \mathrm{yr}$ compared with $\mathrm{N}$ alone at $23.5 \mathrm{t} \mathrm{DM} / \mathrm{ha} / \mathrm{yr}$. To overcome the $\mathrm{N}$ stress in cocksfoot pastures a combination of applied $\mathrm{N}$ in spring, tap rooted perennial legumes in summer and annual clovers in winter is recommended.

Keywords: clover, cocksfoot, crude protein, Dactylis glomerata, leaf photosynthesis, nitrogen, pasture production, potential yield, urine patches
\end{abstract}

\section{Introduction}

Cocksfoot is a persistent perennial grass species used extensively in dryland farming systems. As for all grasses, its total annual dry matter (DM) production is constrained by a combination of environmental and management factors, including cool season temperatures, summer water deficits, available nitrogen (N) supply and grazing interval. Of these, nitrogen supply is the easiest to manipulate on-farm and offers the greatest potential for changing the pattern of feed supply in dryland environments. The strategic use of nitrogen on cocksfoot pastures has received much less research attention than on ryegrass. However, the lack of clover and presence of obvious, more productive dark green urine patches in cocksfoot pastures during all seasons suggests persistent $\mathrm{N}$ stress (Peri et al. 2001). A comparison of urine and non-urine patches throughout the year can be used to indicate the potential yield loss through inadequate $\mathrm{N}$ supply. The advantage of this approach is that it integrates the effects of seasonal changes in temperature and water stress and allows the nitrogen response to be isolated. Joshi et al. (1999) indicated that relief of N stress may approximately double pasture production. Furthermore, an increase in grazing preference for cocksfoot from higher herbage N content is likely (Edwards et al. 1993).

The DM response to urine patches has been reported to last for 2-3 months on ryegrass in the more humid Waikato environment (Ledgard et al. 1982) but no similar data is available for cocksfoot.

Thus, the first objective of this study was to quantify the duration of DM and quality (crude protein) responses of cocksfoot pastures to sheep urine patches. The second objective was to ensure pasture was never nitrogen stressed so that the annual DM yield-loss resulting from nitrogen deficits throughout the year could be estimated.

Finally, the third objective was to explain DM responses using a leaf photosynthesis model that responds to environmental inputs.

\section{Materials and methods \\ Site}

The experiment was located at Lincoln, Canterbury, New Zealand (latitude $43^{\circ} 38^{\prime} \mathrm{S}$, longitude $172^{\circ} 30^{\prime} \mathrm{E}$ ) and was established in September 1990 as an unshaded pasture for comparison with pastures under trees in a silvopastoral experiment. For the current experiment only the four unshaded 'Grasslands Wana' cocksfoot plus 'Grasslands Huia' white clover main plots ( 27.5 x 18.0 m) were measured from September 1999 to May 2001. Clover content of the pasture was low $(<10 \%)$ in all seasons. The soil is classified as a Templeton silt loam (Karageorgis et al. 1984). The average annual evaporation 
is about double the mean rainfall of $660 \mathrm{~mm}$. No fertilizer, lime or irrigation have been applied to the experimental area since its establishment. Soil tests in September 1999 indicated low soil fertility ( $\mathrm{pH} 5.9$, Olsen P $7.5 \mu \mathrm{g} / \mathrm{ml}$, K 0.36 m.e. $\left./ 100 \mathrm{~g}, \mathrm{~S}\left(\mathrm{SO}_{4}\right) 3.5 \mathrm{ppm}\right)$. A flock of Coopworth ewe lambs were rotationally grazed for $7 \pm 1$ days around the four cocksfoot main plots giving a 28 day rotation with $21 \pm 1$ days regrowth.

\section{Urine patches}

Two days after each grazing finished, 10 easily identifiable new sheep urine patches per replicate were identified in the main cocksfoot plots. At the same time paired control areas, adjacent to urine patches, were also selected from within $1 \mathrm{~m}$ of each selected urine patch. This gave a total of 20 sampling points per replicate. The duration of urine patch response was estimated as the time from identification of the patch until no significant difference in DM was measured between urine and nonurine patches. These data were analysed as a completely randomised block design.

\section{Synthetic urine $\mathrm{x}$ irrigation experiment}

A second experiment was established in September 1999. This was designed to examine the maximum productivity and main yield changes in cocksfoot due to $\mathrm{N}$ and irrigation during all seasons. This experiment was conducted in a series of fenced $6.6 \times 6.0 \mathrm{~m}$ areas within the main plots. Irrigation ( 0 or fully) and nitrogen ( 0 or $300 \mathrm{~kg} \mathrm{~N} / \mathrm{ha}$ ) were applied to $2.47 \mathrm{~m}^{2}$ areas as a completely randomised $2 \times 2$ factorial design with two replicates.

The four treatments were monitored for four 60-day regrowth periods (1 September - 30 October 1999; 1 November - 30 December 1999; 6 January - 6 March 2000; and 8 March - 7 May 2000). A further 110-day winter regrowth period was measured from 8 May - 16 August 2000. After each period (60 or 110 days), the next $6.6 \times 6.0 \mathrm{~m}$ area was fenced in a new position in the grazed pastures of the main plot and each treatment was re-imposed. The full irrigation treatment was timed to prevent the soil moisture deficit from exceeding $35 \mathrm{~mm}$, or a reduction in volumetric water content (VWC) of $7 \%$ in the top $500 \mathrm{~mm}$. Over the two seasons a mean of 185 and $287 \mathrm{~mm}$ of water were applied at an average rate of 15-22 mm per application for non- $\mathrm{N}$ and $\mathrm{N}$ treatments, respectively. At the start of each regrowth period a single application of $\mathrm{N}$ as synthetic sheep urine (Fraser et al. 1994) was made.

\section{Environmental and herbage measurements}

Air temperature was recorded with a digital temperature

Figure 1 Mean soil volumetric water content (VWC) (\%) at 0-500 mm soil depth (.- $\cdot$ ) and mean daily air temperature $\left({ }^{\circ} \mathrm{C}\right)(-)$ at Lincoln University (Canterbury). Bars indicate standard error of the mean (SEM) for soil VWC.

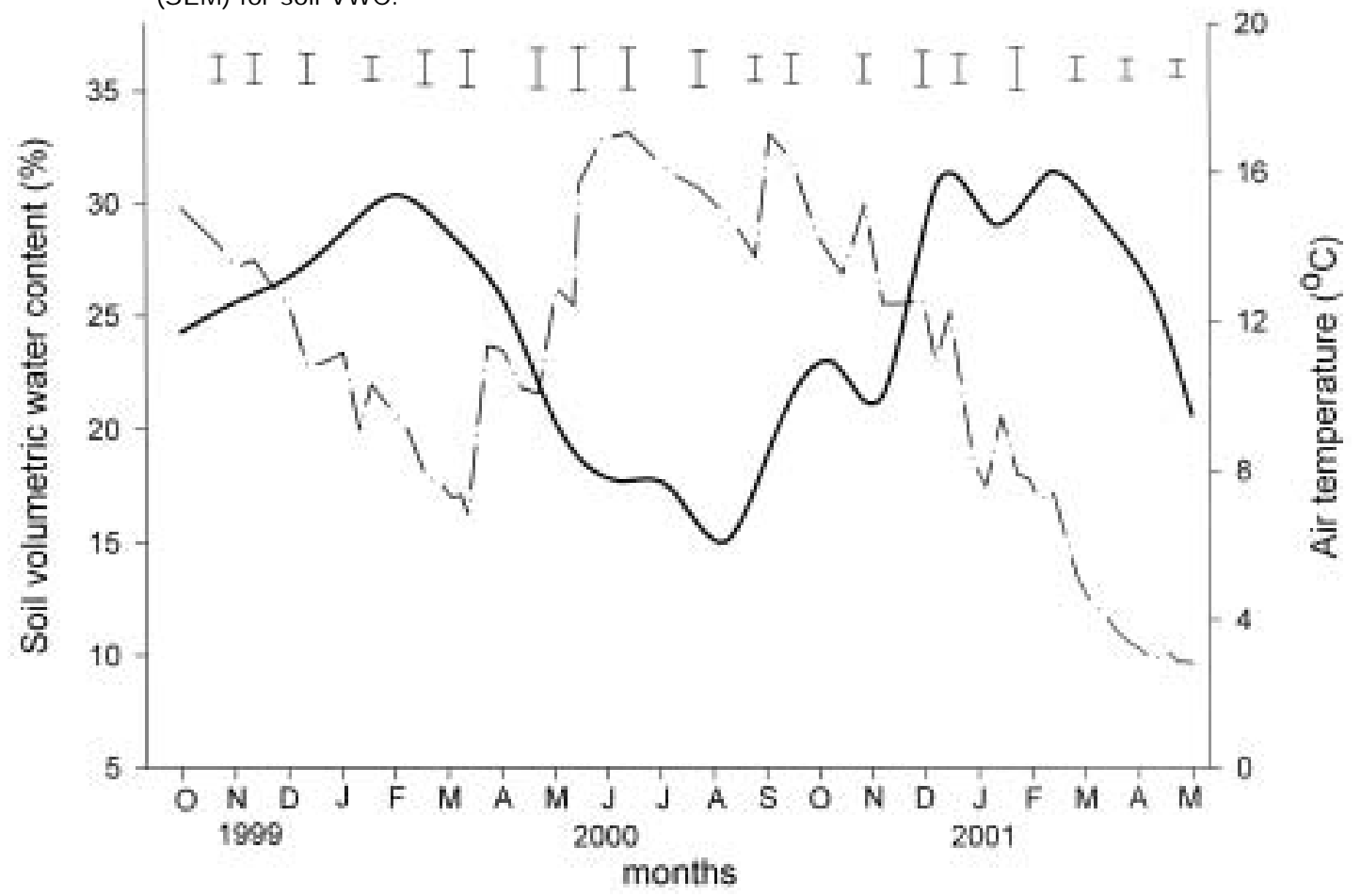


sensor. The seasonal changes in mean daily temperature during the period of this experiment are shown in Figure 1. The mean soil moisture content in the top $500 \mathrm{~mm}$ was measured every 10 days with Time Domain Reflectometry. In spring, soil moisture was always above $24 \%$ and was always more than half the maximum available water content of the site (mean field capacity $=30 \%$ ) indicating that the treatments were not moisture stressed at that time (Figure 1). However, in summer and autumn 2001, pastures were under water stress as indicated by soil VWC lower than $20 \%$.

Pasture samples for DM production were obtained from a $0.2 \mathrm{~m}^{2}$ quadrat cut to $20-25 \mathrm{~mm}$ stubble height. A small circular quadrat (diameter $250 \mathrm{~mm}, 0.05 \mathrm{~m}^{2}$ ) was used to sample individual \pm urine patches (mean diameter ranged from 200 to $300 \mathrm{~mm}$ ). DM samples were dried in a forced draft oven at $65^{\circ} \mathrm{C}$ to constant weight. The herbage $\mathrm{N}$ content from each DM cut was determined using the Kjeldahl technique.

The area which urine patches covered in main plots was measured using six permanent line transects across the cocksfoot pastures in October (spring), January (summer) and April (autumn) of 1999 and 2000. The mean diameter of individual urine patches and the distances between urine patches were measured using a tape placed on transects.
Urine was collected from sheep grazing the cocksfoot pastures to establish the amount of nitrogen applied in urine patches. Urine samples were taken in autumn (18 April 2000) and spring (24 October 2000) from 5 animals and total nitrogen determined using the Kjeldahl technique.

\section{Leaf photosynthesis model}

To evaluate the integrated effect of $\mathrm{N}$, temperature and water stress on DM production in urine patches over time, the multiplicative model for cocksfoot leaves described by Peri et al. (2002) was used. The ranges for predicting net leaf photosynthesis are: (i) air temperatures from 2 to $37^{\circ} \mathrm{C}$, (ii) water status from predawn leaf water potential $\left(\varnothing_{1 \mathrm{p}}\right)-0.1$ to -16.0 bar (corresponding to a soil VWC in the top $500 \mathrm{~mm}$ of 8.5 to $34 \%$ ), (iii) foliage $\mathrm{N}$ content from 1.5 to $5.9 \%$. To predict leaf photosynthetic rate (Pmax), actual values from field measurements of $\mathrm{N}$ content, soil VWC and temperature were used.

\section{Results}

\section{DM growth rate of new urine patches}

The mean area of the plots covered by visually obvious urine patches varied from $25 \%$ in October (1999/2000) to $32 \%$ in April (1999/2000) with a mean patch diameter

Figure 2 Mean cocksfoot dry matter growth rate after $21 \pm 1$ days regrowth from new urine (๑) and paired nonurine (O) patches. Arrows indicate discontinuity in grazing. Bars indicate standard error of the mean (SEM).

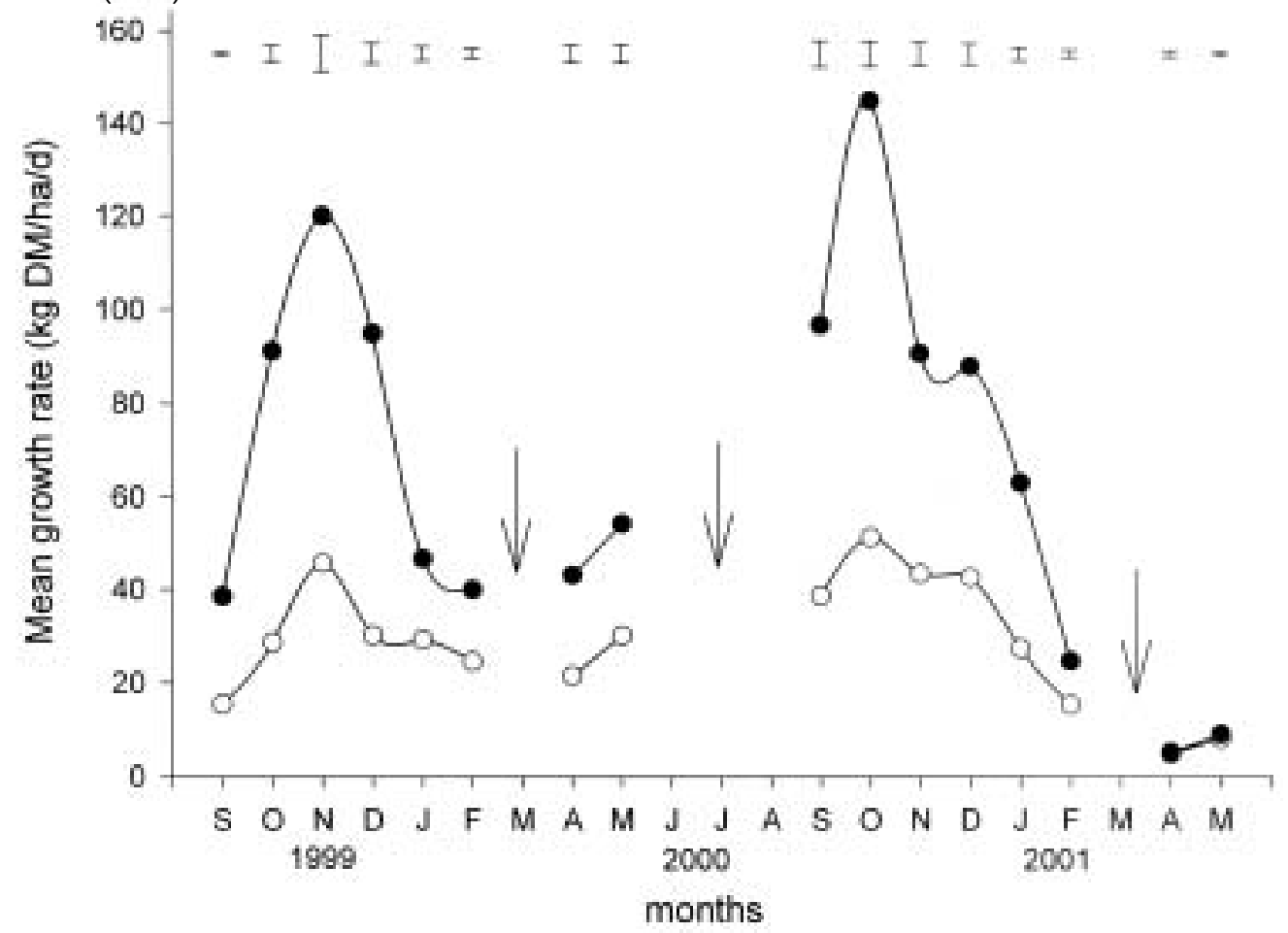


Table 1 Nitrogen $(\mathrm{N})$ concentration of sheep urine in autumn (April) and spring (October) 2000, and the estimated rate of $\mathrm{N}$ applied from sheep urine per hectare to cocksfoot pastures.

\begin{tabular}{lccccc}
\hline & $\begin{array}{c}\mathrm{N} \\
(\mathrm{g} / \mathrm{l})\end{array}$ & $\begin{array}{c}\text { Mean urination } \\
\text { volume }^{1}(\mathrm{l})\end{array}$ & $\begin{array}{c}\mathrm{N} \text { applied per } \\
\text { urination }(\mathrm{g} / \mathrm{l})\end{array}$ & $\begin{array}{c}\text { Mean urination } \\
\text { area }\left(\mathrm{m}^{2}\right)\end{array}$ & $\begin{array}{c}\mathrm{N} \text { in mean urine } \\
\text { patch }(\mathrm{kg} \mathrm{N} / \mathrm{ha})\end{array}$ \\
\hline $\begin{array}{l}\text { Autumn } \\
\text { Spring }\end{array}$ & 3.46 & 0.15 & 0.52 & 0.03 & 173 \\
\hline
\end{tabular}

${ }^{1}$ Mean urination volume from Haynes \& Williams (1993).

of $0.22 \mathrm{~m}$. Sheep urine had a higher $\mathrm{N}$ concentration $(\mathrm{g} /$ 1) in spring (October) than in autumn (April) (Table 1). Results were used to estimate the rate of $\mathrm{N}$ applied per hectare based on a mean urination volume of 0.151 for young sheep (Haynes \& Williams 1993) and ranged from 173 in autumn to $448 \mathrm{~kg} \mathrm{~N} / \mathrm{ha}$ in spring.

The cocksfoot DM growth rates from individual new urine patches compared with non-urine areas are shown in Figure 2. The seasonal fluctuations showed a mean maximum growth rate of $130 \mathrm{~kg} \mathrm{DM} / \mathrm{ha} / \mathrm{d}$ in OctoberNovember for urine patches which was three times higher $(\mathrm{P}<0.05)$ than the non-urine areas. These differences decreased in summer and autumn.

\section{Urine patch dynamics DM production}

The relative difference in DM production between urine and non-urine patches and the duration of the effect of urine patches (when DM was equal to controls) on pasture production varied over seasons (Figure 3). DM production was greater $(\mathrm{P}<0.05)$ than controls at the first rotation (new urine patches), but declined over time. For example, the maximum difference in DM production between urine patches and controls was about $380 \mathrm{~kg} \mathrm{DM} / \mathrm{ha}$ in summer (Figure 3a) and winter (Figure 3b) but up to $1970 \mathrm{~kg} \mathrm{DM} / \mathrm{ha}$ during spring (Figure 3c). The duration of the effect of urine on DM production was estimated at 77 days in summer, 133 days in winter and 105 days in spring.

\section{Crude protein}

The actual values of $\mathrm{CP} \%$, the relative difference in $\mathrm{CP} \%$ between urine patches and controls and the duration of the effect of urine on pasture $\mathrm{CP} \%$ also differed over seasons (Figure 4). The $\mathrm{CP} \%$ was greater $(\mathrm{P}<0.05)$ than controls for the first period (new urine patches) but the difference declined over time. The maximum difference in $\mathrm{CP} \%$ was recorded in spring as $27.0 \%$ for urine and $18.7 \%$ for non-urine patches. The duration of the response to urine for $\mathrm{CP} \%$ was similar to those for DM production (Figure 3).

\section{Leaf photosynthesis}

The mean values of environmental and herbage variables measured during the growing periods of urine patches and controls are summarised in Table 2. The relative difference in net leaf photosynthesis between urine and non-urine patches, and the duration of the

Figure 3 Response over time of dry matter production of cocksfoot from urine $(\bullet)$ and control (O) patches starting in: a) summer (13 December 1999), b) winter (22 March 2000) and c) spring (21 September 2000). Bars indicate standard error of the mean (SEM).

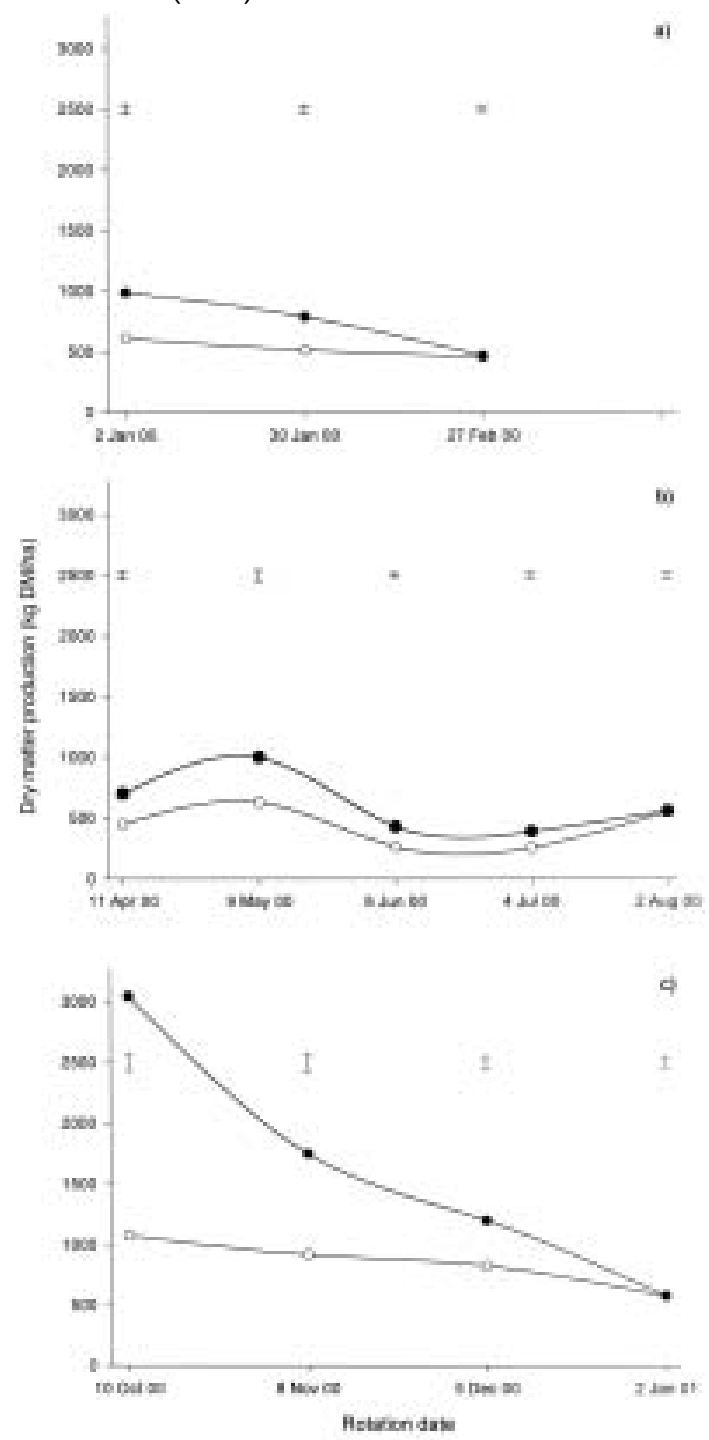


Table 2 Mean (Tmean), maximum (Tmax) and minimum (Tmin) daily temperature, mean nitrogen percentage of grass (N\%), mean monthly photosynthetic photon flux density (PPFD) and mean volumetric water content (VWC) in the top $500 \mathrm{~mm}$ of soil for three growing periods in urine and non-urine patches. Values were used to predict leaf photosynthetic rate of cocksfoot plants at Lincoln University (Canterbury).

\begin{tabular}{llrrrrrrr}
\hline Season & \multicolumn{1}{c}{ Date } & $\begin{array}{c}\text { Tmean } \\
\left({ }^{\circ} \mathrm{C}\right)\end{array}$ & $\begin{array}{c}\text { Tmax } \\
\left({ }^{\circ} \mathrm{C}\right)\end{array}$ & $\begin{array}{c}\text { Tmin } \\
\left({ }^{\circ} \mathrm{C}\right)\end{array}$ & $\begin{array}{c}\mathrm{N} \text { urine } \\
(\%)\end{array}$ & $\begin{array}{r}\mathrm{N} \text { control } \\
(\%)\end{array}$ & $\begin{array}{c}\text { PPFD } \\
\left(\mathrm{mol} / \mathrm{m}^{2} / \mathrm{month}\right)\end{array}$ & $\begin{array}{c}\text { VWC } \\
(\%)\end{array}$ \\
\hline Summer & 2 J an-27 Feb 00 & 15.0 & 20.5 & 11.5 & 2.8 & 2.2 & 1620 & 19.2 \\
Winter & 11 Apr-2 Aug 00 & 8.8 & 14.1 & 5.0 & 4.1 & 3.0 & 450 & 29.0 \\
Spring & 10 Oct 00-2 Jan 01 & 12.3 & 18.6 & 7.8 & 3.7 & 2.9 & 1560 & 23.8 \\
\hline
\end{tabular}

Note: Mean nitrogen content was calculated based on crude protein data over duration of urine patch from Figure 4.

Figure 4 Response over time of crude protein percentage of cocksfoot from urine (•) and control (o) patches starting in: a) summer (13 December 1999), b) winter (22 March 2000) and c) spring (21 September 2000). Bars indicate standard error of the mean (SEM).

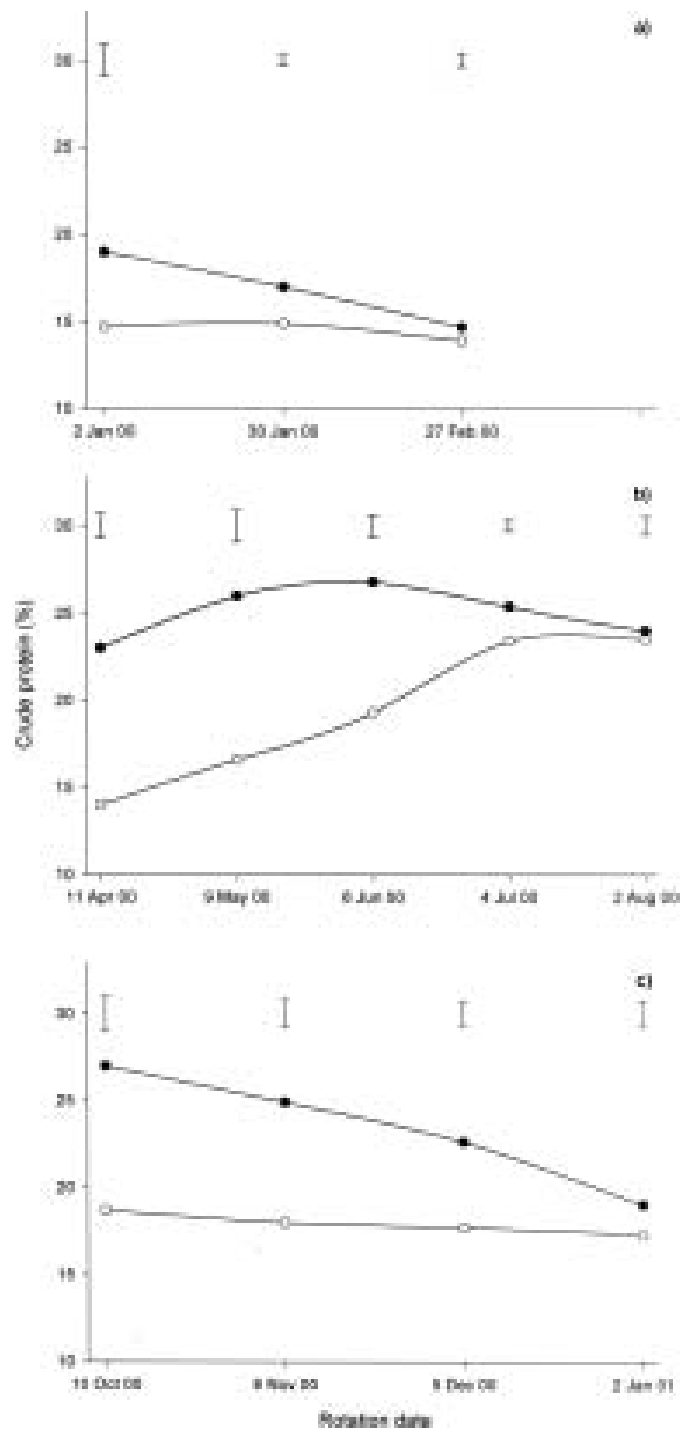

Figure 5 Response over time of predicted leaf photosynthetic rates of cocksfoot urine (๑) and control (o) patches starting in: a) summer (13 December 1999), b) winter (22 March 2000) and c) spring (21 September 2000).

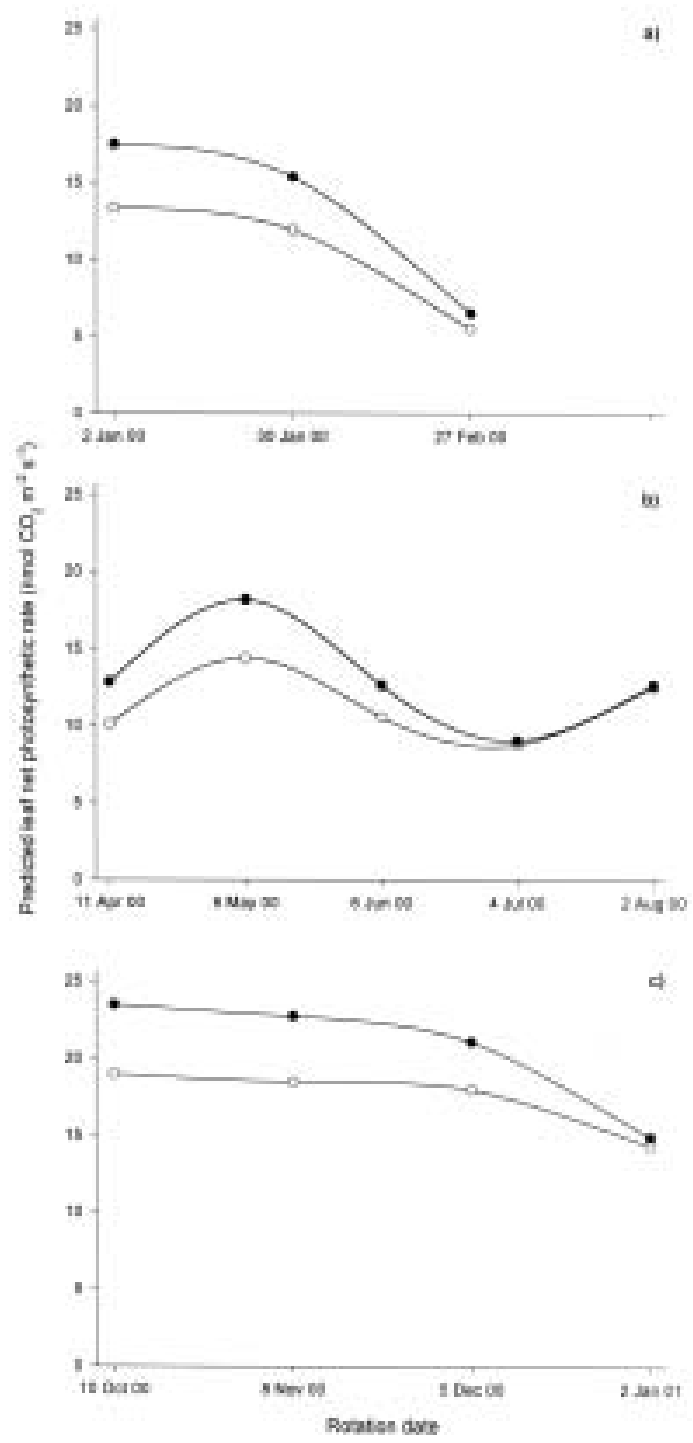


effect of urine patches, also differed between seasons. The range was from 23.5 in October to $4.5 \mu \mathrm{mol} \mathrm{CO}_{2}$ $\mathrm{m}^{-2} \mathrm{~s}^{-1}$ in February 2000 (Figure 5). The maximum difference in net leaf photosynthesis between urine patches and controls was greater $(\mathrm{P}<0.05)$ after the first 21 day rotation (new urine patches). Specifically, Pmax values were 17.5 vs $13.4 \mu \mathrm{mol} \mathrm{CO}_{2} \mathrm{~m}^{-2} \mathrm{~s}^{-1}$ in summer (Figure 5a), 18.1 vs $14.4 \mu \mathrm{mol} \mathrm{CO} \mathrm{C}^{-2} \mathrm{~s}^{-1}$ in winter (Figure 5b) and $23.5 \mathrm{vs} 19.0 \mu \mathrm{mol} \mathrm{CO} \mathrm{m}^{-2} \mathrm{~s}^{-1}$ in spring (Figure 5c), for urine vs control patches, but differences declined over time. The duration of the response to urine on leaf photosynthesis was the same as that found for DM production in each season.

\section{DM production and growth rate from the synthetic urine $x$ irrigation experiment}

On average, the application of $\mathrm{N}$ increased $(\mathrm{P}<0.001)$ the annual yield by $\sim 14 \mathrm{t} \mathrm{DM} / \mathrm{ha} / \mathrm{yr}$ and irrigation increased $(\mathrm{P}<0.05)$ annual yield by $\sim 4.4 \mathrm{t} \mathrm{DM} / \mathrm{ha} / \mathrm{yr}$ (Table 3). There were no interactions between irrigation and $\mathrm{N}$ for any season.

\section{Discussion}

The maximum potential DM production was $28.6 \mathrm{t} / \mathrm{ha} /$ $\mathrm{yr}$ for this sub-humid temperate environment. This was achieved from exclosure plots that were fully irrigated, received $300 \mathrm{~kg} \mathrm{~N} / \mathrm{ha}$ as synthetic urine in each of five regrowth periods and were allowed to regrow for 60 110 days after grazing. This result is similar to yields reported in the Netherlands for perennial ryegrass (28 t/ ha) when $125 \mathrm{~kg} \mathrm{~N} / \mathrm{ha}$ and $62 \mathrm{~kg} \mathrm{~K} / \mathrm{ha}$ were applied in each regrowth period (Alberda \& Sibma 1968). To achieve these yields growth rates over $150 \mathrm{~kg} \mathrm{DM} / \mathrm{ha} / \mathrm{d}$ (Figure 2) are required which are consistent with those reported by Lemaire et al. (1983) for cocksfoot grown in France.

In practice this yield is unlikely to be achieved. Grazing management would aim to minimize the amount of reproductive material in the pasture, which contributed nearly $2 \mathrm{t} / \mathrm{ha}$, and the rotation length would be shorter than the 60 day exclosures used during the growing season in this study. However, these results do provide insights into the environmental and

Table 3 Accumulated dry matter ( $\mathrm{kg} \mathrm{DM} / \mathrm{ha}$ ) for different regrowth periods and total annual production (t DM/ha) for cocksfoot pastures at two irrigation ( 0 or fully) and two nitrogen ( 0 or $300 \mathrm{~kg} \mathrm{~N} / \mathrm{ha}$ ) levels. Regrowth periods were 60 days for spring, summer and autumn and 110 days for winter (May-August 2000).

\begin{tabular}{|c|c|c|c|c|c|c|}
\hline \multirow[b]{2}{*}{ Treatment } & \multicolumn{6}{|c|}{------------- Regrowth period -------------} \\
\hline & Sep-0ct 99 & Nov-Dec 99 & $\begin{array}{r}\text { J an-Feb } 00 \\
\text { (kg DM/ha) }\end{array}$ & Mar-Apr 00 & May-Aug 00 & $\begin{array}{l}\text { Total annual } \\
\text { (t DM/ha/yr) }\end{array}$ \\
\hline $\begin{array}{l}\text { Control } \\
\text { Irrigated } \\
\mathrm{N} \\
\text { Irrigated + N }\end{array}$ & $\begin{array}{l}2650 \\
2650^{\#} \\
5380 \\
5380^{\#}\end{array}$ & $\begin{array}{l}3260 \\
5340 \\
7620 \\
8970\end{array}$ & $\begin{array}{c}920 \\
2230 \\
3540 \\
5980\end{array}$ & $\begin{array}{c}980 \\
1440 \\
3410 \\
4690\end{array}$ & $\begin{array}{l}1390 \\
1390^{\#} \\
3540 \\
3540^{\#}\end{array}$ & $\begin{array}{r}9.2 \\
13.0 \\
23.5 \\
28.6\end{array}$ \\
\hline $\begin{array}{l}\text { SEM } \\
\text { Significance }\end{array}$ & 110.1 & 98.7 & 501.2 & 120.7 & 250.9 & 0.46 \\
\hline Irrigation & - & *t* & $*$ & ** & - & $*$ \\
\hline$N$ & wak & wak & wak & *** & *** & *** \\
\hline Irrigation x N & ns & ns & ns & ns & ns & ns \\
\hline
\end{tabular}

\# Irrigation was not required, therefore values are the same as non-irrigated treatments.

$\mathrm{P}<0.05 ;$ ** $\mathrm{P}<0.01 ;$ *** $\mathrm{P}<0.001 ; \mathrm{ns}=$ no significant differences.

The added nitrogen at least doubled $(\mathrm{P}<0.001)$ DM growth rates in all growth periods. The main period of $\mathrm{N}$ response was November-December 1999. This was caused by a production rate of 154 $\mathrm{kg} \mathrm{DM} / \mathrm{ha} / \mathrm{d}$ when water was non-limiting (mean soil VWC> 23\%) and mean air temperature was $13.5^{\circ} \mathrm{C}$. This was also attributed to the production from reproductive tillers. For example, in irrigated plus $\mathrm{N}$ fertilized pastures, the reproductive DM accumulated after 60 days regrowth was $1920 \mathrm{~kg}$ $\mathrm{DM} / \mathrm{ha}$ ( $21 \%$ of total). Pasture DM production with $\mathrm{N}$ decreased $(\mathrm{P}<0.001)$ to $32 \mathrm{~kg} \mathrm{DM} / \mathrm{ha} / \mathrm{d}$ in winter (May-August period) when the mean air temperature was only $7.0^{\circ} \mathrm{C}$. management constraints operating on annual cocksfoot pasture production.

\section{Spring response to $\mathbf{N}$}

The large response to $\mathrm{N}$ in all seasons increased yield from 9.2 to $23.5 \mathrm{t} / \mathrm{ha}$ compared with $13.0 \mathrm{t} / \mathrm{ha}$ when only water was added (Table 3 ). The strong $\mathrm{N}$ response was particularly apparent during the spring (Figure 2). This highlights the potential production loss from the typical state of $\mathrm{N}$ stress. Specifically, the nitrogen fertilised artificial urine patches produced $2 \mathrm{t} / \mathrm{ha}$ more than control patches by October $10^{\text {th }}$. This response occurred when soil moisture content and temperature were non-limiting and implies that the cocksfoot pastures were severely 
nitrogen deficient during this time. The leaf photosynthesis results highlight this limitation with urine patch areas operating at near maximum (Peri et al. 2002) values and control plots approximately $20 \%$ lower throughout the spring/early summer period (Figure 5c). Simply, this indicates a $20 \%$ reduction in potential photosynthesis per leaf per day that accumulates to cause the observed reduction in DM yield.

The crude protein results support the assumption that $\mathrm{N}$ stress has a large negative effect on spring production. The urine patches had a maximum value of $27 \% \mathrm{CP}$ in October, which is equivalent to a leaf $\mathrm{N}$ concentration of $4.4 \%$, compared with only $18 \% \mathrm{CP}$ or $2.9 \%$ leaf $\mathrm{N}$ in the controls (Figure 4c).

The direct result of these differences in leaf $\mathrm{N}$ concentration would be a $20 \%$ lower leaf photosynthesis rate as estimated for the control plots compared with the urine patches (Figure 5c). The difference between patches decreased later in the spring as the extra dry matter production in the urine patches (Figure 2) diluted the additional available $\mathrm{N}$, so that by $2^{\text {nd }}$ January the $\mathrm{CP}$ values were both about 20\% (Figure 4c). Thus, despite the high $\mathrm{N}$ concentration (448 $\mathrm{kg} \mathrm{N} / \mathrm{ha}$ ) in the urine during spring time (Table 1) the leaf photosynthesis in urine and non-urine patch areas would be severely restricted by the leaf $\mathrm{N}$ concentration of $2.4 \%$ (Figure $5 c)$. A secondary effect of the low leaf $\mathrm{N}$ is likely to be a reduction in grazing preference during this period (Edwards et al. 1993), except for in any new urine patches.

\section{Summer response to $\mathbf{N}$}

As expected, during summer both $\mathrm{N}$ and moisture stresses were observed. The DM production of urine patches was only $38 \%$ higher than controls in the first January rotation (Figure 3a). This smaller response reflects the combination of low leaf $\mathrm{N}(2.8 \%)$ and a mean soil VWC of less than 20\% (Figure 1). The leaf photosynthesis rates during this period reflect the $25 \%$ increase from the urine patches but this value was only $70 \%$ of the maximum and declined to be similar to the non-urine rate $(6 \mu \mathrm{mol}$ $\mathrm{CO}_{2} \mathrm{~m}^{-2} \mathrm{~s}^{-1}$ ) in February (Figure 5a) as water stress became more severe (Figure 1).

The implication was that during periods when the top soil was dry the added urine $\mathrm{N}$ was largely unavailable to the plants. This is consistent with a restriction in the movement of nitrate and ammonium ions from the urine patches to the plant during such periods, even when water is available from depth in the profile (Lemaire \& Denoix 1987). Similarly, Garwood \& Williams (1967) reported that during periods of drought, which dry out the soil surface $(150-200 \mathrm{~mm})$, there is reduced $\mathrm{N}$ uptake and mineralisation of organic $\mathrm{N}$.

During this summer period the increase in DM production from urine patches lasted about 2 months (Figure 3a) which was consistent with previous studies (During \& McNaught 1961; Ledgard et al. 1982). The continued water stress meant grazing had to be discontinued in late February and March of both seasons (Figure 1). Thus, any possible relief from applied nitrogen during this period would be of limited effectiveness because of severe soil moisture deficit.

\section{Winter response to $\mathrm{N}$}

By winter, the $\mathrm{N}$ content in non-urine areas was still deficient and mean air temperatures were sub optimal at $<9^{\circ} \mathrm{C}$ (Figure 1) but soil moisture levels were nonlimiting (Table 2). As a consequence leaf photosynthesis was restricted mainly by temperature during this period (Figure 5b). It follows that $\mathrm{N}$ demand would be low with the slow growth (Figure 2) which is consistent with the extended duration of response (133 days) for the urine patches.

Despite the restrictions on photosynthesis and growth by low temperature the crude protein of urine patches averaged about $25 \%$ through the autumn and winter compared with the increase from 14 to $23 \%$ observed for the controls from April to July (Figure 4b).

\section{Management of $\mathrm{N}$ stress in cocksfoot pastures}

The overall differences in seasonal responses of cocksfoot DM production highlight the importance of understanding the environmental and management constraints to develop an effective strategy to maximise production. The results of this study highlight low $\mathrm{N}$ status of cocksfoot in non-urine patches throughout the year. This has been shown to limit pasture production by restricting photosynthesis rates but is also likely to influence grazing preference of cocksfoot based pastures. Thus, a three pronged $\mathrm{N}$ management strategy is proposed. Firstly, the application of artificial $\mathrm{N}$ in the spring, when moisture is non-limiting and temperature rising is expected to produce the greatest DM response per unit of $\mathrm{N}$ applied. However, further applications of $\mathrm{N}$ fertiliser in summer and autumn appear unjustified. This is because without water the $\mathrm{N}$ would not be utilised in summer and low temperatures will restrict winter growth. The introduction of tap-rooted legumes, such as Caucasian clover to access moisture below the cocksfoot rooting zone may provide an opportunity for improving the leaf $\mathrm{N}$ concentration and palatability of pastures in summer. Similarly, the greater winter activity of annual clovers may provide a source of nitrogen to maintain leaf $\mathrm{N}$ levels when temperatures are low in late autumn and winter.

\section{Conclusions}

1) Cocksfoot pasture production was limited by 
nitrogen supply, which affects leaf photosynthesis rates, in all seasons.

2) The magnitude of DM response to applied $\mathrm{N}$ was greatest in the spring but restricted by moisture stress in summer and low temperatures in winter.

3) It is proposed that the productivity and the palatability of cocksfoot may increase by relieving $\mathrm{N}$ stress through fertiliser application in spring and the inclusion of tap rooted perennial and annual clovers may enhance summer and autumn/winter production, respectively.

\section{REFERENCES}

Alberda, Th.; Sibma, L. 1968. Dry matter production and light interception of crop surface. III. Actual herbage production in different years, as compared with potential values. Journal of the British Grassland Society 23: 206-215.

During, C.; McNaught, K.J. 1961. Effect of cow urine on growth of pasture and uptake of nutrients. New Zealand Journal of Agricultural Research 4: 591605.

Edwards, G.R.; Lucas, R.J.; Johnson, M.R. 1993. Grazing preference for pasture species by sheep is affected by endophyte and nitrogen fertility. Proceedings of the New Zealand Grassland Association 55: 137-141.

Fraser, P.M.; Cameron, K.C.; Sherlock, R.P. 1994. Lysimeter study of the rate of nitrogen in animal urine returns to irrigated pasture. European Journal of Soil Science 45: 439-447.

Garwood, E.A.; Williams, T.E. 1967. Nutrient uptake by grass swards. Journal of Agricultural Science, Cambridge, 69:125-130.

Haynes, R.J.; Williams, P.H. 1993. Nutrient cycling and soil fertility in the grazed pasture ecosystem.
Advances in Agronomy 49: 119-199.

Joshi, M.R.; Lucas, R.J.; Sedcole, J.R; Pollock, K.M.; Moot, D.J.; Mead, D.J. 1999. Shading effects of Pinus radiata on productivity and feeding value of orchardgrass pasture. Agroforestry Forum 9 (3): 17-19.

Karageorgis, D.; Tonkin, P.J.; Adams, J.A. 1984. Medium and short range variability in textural layering in an Ochrept developed on an alluvial flood plain. Australian Journal of Soil Research 22: 471474.

Ledgard, S.F.; Steele, K.W.; Saunders, W.H.M. 1982. Effects of cow urine and its major constituents on pasture properties. New Zealand Journal of Agricultural Research 25: 61-68.

Lemaire, G.; Salette, J.; Gosse, G.; Chartier, M. 1983. Temperature and spring growth for grasses: comparison of different grass stands. pp. 255-261. In: Efficient Grassland Farming. Ed. Corral, A.J. Occasional Symposium of the British Grassland Society, U.K.

Lemaire, G.; Denoix, A. 1987. Summer dry matter accumulation in Festuca arundinacea and Dactylis glomerata populations in Western France. II. Interaction between moisture level and nitrogen nutrition. Agronomie 7: 381-389.

Peri, P.L.; Varella, A.C.; Lucas, R.J.; Moot, D.J. 2001. Cocksfoot and lucerne productivity in a Pinus radiata silvopastoral system: a grazed comparison. Proceedings of the New Zealand Grassland Association 63: 139-147.

Peri, P.L.; Moot, D.J.; McNeil, D.L.; Varella, A.C.; Lucas R.J. 2002. Modelling net photosynthetic rate of field-grown cocksfoot leaves under different nitrogen, water and temperature regimes. Grass and Forage Science 57: 61-71. 